\title{
KONSTITUSIONALITAS PEMBERLAKUAN PERPPU PEMILUKADA DAN IMPLIKASINYA TERHADAP PENUNDAAN PEMILUKADA SERENTAK TAHUN 2020
}

\section{(The Constitutional Basis of Government Regulation in Lieu of Law on Regional General Election and its Implication on the Postponement of Simultaneous Regional General Election 2020)}

\author{
Farida Azzahra dan Aloysius Eka Kurnia \\ Pascasarjana Fakultas Hukum Universitas Indonesia \\ Program Studi IImu Hukum Fakultas Hukum Universitas Indonesia \\ Jalan Salemba Raya Nomor 4 \\ DKI Jakarta \\ Email: faridaazzahra11@gmail.com dan ekakur02@gmail.com
}

\begin{abstract}
Abstrak
Peraturan perundang-undangan terkait Pemilu di Indonesia saat ini belum mengatur mengenai kewenangan KPU untuk menunda pelaksanaan Pemilukada serentak serta menetapkan jadwal Pemilihan ulang. Adapun meski Undang-Undang Nomor 1 Tahun 2015 melegitimasi penundaan penyelenggaraan Pemilukada akibat terjadinya sebuah bencana, namun Undang-Undang a quo tidak menjelaskan perihal lembaga mana yang berwenang menunda penyelenggaraan Pemilukada jika bencana yang dimaksud adalah bencana nasional. Atas hal tersebut, Presiden melalui Perppu Nomor 2 Tahun 2020 telah mengeluarkan dasar hukum guna mengatur kewenangan KPU dalam menunda dan menetapkan jadwal pelaksanaan Pemilukada serentak. Untuk itu, penelitian ini bermaksud untuk meneliti konstitusionalitas Perppu tersebut beserta implikasinya terhadap pelaksanaan Pemilukada. Permasalahan yang akan ditinjau dalam penelitian ini akan menyangkut persoalan mengenai bagaimana kedudukan KPU dalam pelaksanaan Pemilukada di Indonesia serta bagaimana konstitusionalitas Perppu tersebut. Adapun metode penelitian yang digunakan adalah metode yuridis normatif. Hasil penelitian menunjukan bahwa pemberlakuan Perppu tersebut merupakan bentuk upaya mencegah terjadinya kekosongan hukum dalam penyelenggaraan Pemilukada di tengah situasi penyebaran Covid-19. Hal ini berlaku konstitusional dan bukan merupakan bentuk intervensi pemerintah terhadap kemandirian lembaga negara.
\end{abstract}

Kata Kunci: Perppu, Pemilukada, Konstitusi

\begin{abstract}
The existing laws about the election in Indonesia haven't regulate the authority of the General Election Commission (KPU) to postpone the implementation of the general election. The a quo Law also doesn't explain which institution has the authority to postpone the election if the national disaster happened. For this reason, the President through government regulation in lieu of law No.2 of 2020 (Perppu) has issued a legal basis to regulate the KPU's authority in postponing the regional election simultaneously. Therefore, this research intends to examine the constitutionality of the Perppu and its implications for the regional election. This research used a normative juridical method. The results shows that the implementation of Perppu is a form of effort to prevent a legal vacuum of the election in the midst of the situation of Covid-19. This applies constitutionally and is not a form of government intervention on the independence of state institutions.
\end{abstract}

Keywords: The Government Regulation in lieu of Law, Regional Election, Constitution

\section{A. Pendahuluan}

Kewenangan untuk menunda penyeleng- garaan Pemilukada serentak 2020 akibat penyebaran Pandemi Covid-19 yang telah men- 
jangkau 270 daerah pemilihan di Indonesia seharusnya dapat menjadi bagian dari kewenangan Komisi Pemilihan Umum (KPU). Adapun Pemilihan Umum (Pemilu) itu sendiri pada ketentuan Pasal 22E Ayat (5) UndangUndang Dasar Negara Republik Indonesia 1945 (selanjutnya disebut UUD NRI 1945) dalam prosesnya harus dilaksanakan oleh suatu komisi yang mandiri sebagaimana hal tersebut selayaknya dijalankan oleh KPU. Oleh karena itu, ketika Undang-Undang Nomor 1 Tahun 2015 tentang Penetapan Peraturan Pemerintah Pengganti Undang-Undang Nomor 1 Tahun 2014 tentang Pemilihan Gubernur, Bupati, dan Walikota Menjadi Undang-Undang (selanjutnya disebut Undang-Undang Pemilukada) dalam pengaturannya tidak mengatribusikan kewenangan yang dimaksud kepada KPU, maka dibutuhkan Peraturan Pemerintah Pengganti Undang-Undang (Perppu) sebagai jenis peraturan yang dapat mengakomodir pengatribusian kewenangan tersebut dalam situasi kedaruratan yang terjadi.

Sebagaimana diketahui, sistem ketatanegaraan Indonesia saat ini mengenal lima bentuk Pemilu, yakni Pemilu Presiden dan Wakil Presiden, Pemilu Anggota Legislatif Dewan Perwakilan Rakyat (DPR), Pemilihan Umum Anggota Dewan Perwakilan Daerah (DPD), Pemilihan Umum Anggota Dewan Perwakilan Rakyat Daerah (DPRD) yang terdiri dari DPRD Provinsi dan DPRD Kabupaten/Kota, serta Pemilihan Umum Kepala Daerah yang terdiri dari
Gubernur, Bupati dan Walikota (Pemilukada). Kendati di dalam UUD NRI 1945 tidak disebutkan secara tegas perihal mekanisme Pemilihan untuk memilih Gubernur, Bupati, maupun Walikota, namun menurut Rozali Abdullah mekanisme Pemilihan Kepala Daerah dan Wakil Kepala Daerah sudah seharusnya dibentuk secara sinkron dengan mekanisme yang dipakai untuk memilih Presiden dan Wakil Presiden Republik Indonesia. ${ }^{1}$ Adapun hal tersebut didasarkan atas pemahaman bahwa daerah merupakan bagian yang tidak terpisahkan dari Negara Kesatuan Republik Indonesia (NKRI) yang mana hal tersebut juga mengartikan perlunya kesatuan sistem dalam hal pemilihan untuk pimpinan pemerintahan di pusat maupun di daerah. ${ }^{2}$

Pemilihan Kepala Daerah di Indonesia saat ini dilaksanakan melalui mekanisme Pemilukada serentak. Adapun maksud dari Pemilukada serentak adalah pemilihan langsung kepala daerah oleh masyarakat di satu daerah melalui mekanisme pemungutan suara yang dilaksanakan bersamaan dengan pemungutan suara pada pemilihan kepala daerah di daerah lainnya. ${ }^{3}$ Mekanisme Pemilukada serentak ini pertama kali dilaksanakan pada tahun 2015 dan berlanjut di tahun 2018. Dalam perencanaannya menurut Undang-Undang Pemilukada, mekanisme Pemilukada serentak juga sedianya akan dilaksanakan untuk memilih kepala daerah di 270 daerah pemilihan di Indonesia pada tahun 2020.

Pelaksanaan Pemilukada serentak tahun

Rozali Abdullah, Pelaksanaan Otonomi Luas dengan Pemilihan Kepala Daerah Secara Langsung, (Jakarta: Rajawali Pers, 2005), hlm. 53.

Ibid.

Pada ketentuan peralihan di dalam Undang Undang Pemilukada dijelaskan bahwa pemungutan suara serentak dilaksanakan di tahun yang sama dimana kepala daerah pada daerah tersebut akan mengakhiri masa tugasnya. Republik Indonesia, Undang Undang Tentang Penetapan Peraturan Pemerintah Pengganti Undang-Undang Nomor 1 Tahun 2014 tentang Pemilihan Gubernur, Bupati, dan Walikota Menjadi Undang-Undang, UU No. 1 Tahun 2015, Lembaran Negara RI No. 245 Tahun 2014, Pasal 201 Ayat (1), Ayat (2), dan Ayat (4). 
2020 sebagaimana diamanatkan oleh UndangUndang Pemilukada diatur lebih lanjut di dalam Peraturan Komisi Pemilihan Umum Nomor 15 Tahun 2019 tentang Tahapan, Program, dan Jadwal Penyelenggaraan Gubernur dan Wakil Gubernur, Bupati dan Wakil Bupati, dan/atau Walikota dan Wakil Walikota Tahun 2020 (selanjutnya disebut PKPU No. 15 Tahun 2019). Pada bagian Lampiran PKPU No. 15 Tahun 2019, disebutkan bahwa pelaksanaan pemungutan suara untuk Pemilukada tahun 2020 sedianya akan dilaksanakan pada tanggal 23 September 2020. Akan tetapi, rencana penyelenggaraan Pemilukada tahun 2020 tersebut harus tertunda akibat adanya penyebaran Pandemi Covid-19 yang melumpuhkan seluruh sektor pembangunan.

Pandemi Covid-19 pertama kali ditetapkan sebagai bencana yang mengakibatkan kedaruratan kesehatan masyarakat melalui Keputusan Presiden Nomor 11 Tahun 2020 tentang Penetapan Kedaruratan Kesehatan Masyarakat Corona Virus Disease 2019 (Covid-19) (selanjutnya disebut Keppres Nomor 11 Tahun 2020). ${ }^{4}$ Melalui Keppres Nomor 11 Tahun 2020 tersebut, muncul beragam kebijakan untuk menanggulangi penyebaran Pandemi Covid-19 yang salah satunya adalah kebijakan Pembatasan Sosial Berskala Besar
(PSBB). ${ }^{5}$ Kebijakan PSBB yang diterapkan oleh banyak Pemerintah Daerah untuk menekan angka penularan Covid-19 kemudian berdampak langsung terhadap penyelenggaraan Pemilukada 2020 yang harus tertunda untuk waktu yang belum dapat ditentukan. ${ }^{6}$

Penundaan dan pelaksaanaan Pemilukada susulan dalam pengaturannya telah diatur di dalam Undang-Undang Pemilukada atas dasar syarat-syarat tertentu apabila pada sebagian daerah pemilihan mengalami bencana alam, kerusuhan, dan/atau gangguan lainnya. ${ }^{7}$ Akan tetapi, penundaan yang dimaksud dalam Undang-Undang Pemilukada ini hanya bersifat lokal dan tidak dapat mengakomodir penundaan Pemilukada yang bersifat nasional. ${ }^{8}$ Selain itu, mekanisme penundaan juga dilakukan dengan tahapan yang berjenjang.

Ketiadaan dasar hukum terkait penundaan dan penjadwalan ulang Pemilukada tahun 2020 yang sesuai dengan kondisi kedaruratan kesehatan masyarakat akibat Pandemi Covid-19 memunculkan inisiatif dari Pemerintah untuk menerbitkan Peraturan Pemerintah Pengganti Undang-Undang Nomor 2 Tahun 2020 tentang Perubahan Ketiga Atas Undang Undang Nomor 1 Tahun 2015 Tentang Penetapan Peraturan Pemerintah Pengganti Undang-Undang Nomor 1 Tahun 2014 tentang Pemilihan Gubernur,

$4 \quad$ Keputusan Presiden ini didasarkan atas ketentuan dari Undang Undang Kekarantinaan Kesehatan yang mengakomodir pemberlakuan kekarantinaan kesehatan oleh Pemerintah terhadap masyarakat akibat sebuah wabah penyakit. Republik Indonesia, Undang Undang Kekarantinaan Kesehatan, UU No. UU No. 6 Tahun 2018, Lembaran Negara RI No. 128 Tahun 2018, Pasal 10 ayat (1).

$5 \quad$ Kebijakan PSBB adalah pembatasan kegiatan tertentu penduduk dalam suatu wilayah yang diduga terinfeksi Corona Virus Disease 2019 (COVID-19). Pembatasan yang ada dapat diterapkan di suatu daerah atas permohonan yang dibuat oleh Kepala Daerah bersangkutan. Republik Indonesia, Peraturan Menteri Kesehatan Tentang Pedoman Pembatasan Sosial Berskala Besar Dalam Rangka Percepatan Penanganan Corona Virus Disease 2019 (Covid-19), Permenkes No. 9 Tahun 2020, Berita Negara RI No. 326 Tahun 2020, Pasal 3 Ayat (1).

$6 \quad$ Pada ketentuan PSBB terdapat beberapa pembatasan kegiatan menghimpun sejumlah masyarakat. Ibid., Pasal 13 ayat (1).

7 Republik Indonesia, Undang Undang Tentang Penetapan Peraturan Pemerintah Pengganti Undang-Undang Nomor 1 Tahun 2014 tentang Pemilihan Gubernur, Bupati, dan Walikota Menjadi Undang-Undang, Undang-Undang Nomor 1 Tahun 2015, Lembaran Negara RI No. 245 Tahun 2014, Pasal 120 Ayat (1).

8 Ibid., Pasal 120 ayat (1) dan Pasal 121 ayat (1). 
Bupati, dan Walikota Menjadi Undang-Undang (selanjutnya disebut Perppu Nomor 2 Tahun 2020). Pemberlakuan Perppu Nomor 2 Tahun 2020 oleh Pemerintah dimaksudkan agar penundaan Pemilukada tahun 2020 memiliki dasar hukum yang mengikat dan sesuai dengan kondisi negara yang sedang memberlakukan kedaruratan kesehatan masyarakat dan kebijakan PSBB akibat Pandemi Covid-19.

Perppu Nomor 2 Tahun 2020 yang ditetapkan oleh Presiden selain mengakomodir ketentuan mengenai penundaan Pemilukada akibat wabah penyakit yang terjadi dalam skala nasional, juga menetapkan KPU sebagai lembaga yang berwenang untuk menetapkan tanggal Pemilukada serentak lanjutan. ${ }^{9}$ Akan tetapi, sekalipun kewenangan untuk menetapkan tanggal Pemilukada lanjutan berada pada KPU, Perppu No. 2 Tahun 2020 telah menetapkan terlebih dahulu bulan Desember 2020 sebagai waktu pemungutan suara dalam Pemilukada serentak tahun $2020 .^{10}$

Keberadaan Perppu Nomor 2 Tahun 2020 di satu sisi merupakan sebuah wadah untuk memperjelas upaya penundaan Pemilukada serentak tahun 2020 yang diakibatkan oleh Pandemi Covid-19. Namun, di sisi lain, keberadaan Perppu Nomor 2 Tahun 2020 juga ditafsirkan sebagai perintah dari Pemerintah kepada KPU untuk menyelenggarakan Pemilukada serentak lanjutan sesuai dengan kriteria yang dibentuk oleh Pemerintah melalui Perppu Nomor 2 Tahun 2020 tersebut.

Penelitian ini akan menganalisis mengenai landasan konstitusional dari pemberlakuan Perppu Nomor 2 Tahun 2020 sebagai instru- men hukum yang memberikan alternatif penyelesaian masalah perihal kewenangan penundaan Pemilukada serentak Tahun 2020. Untuk memberikan analisa yang komprehensif sebagaimana tujuan penelitian ini maka penelitian ini akan menjawab dua pertanyaan hukum, yaitu: (1) Bagaimanakah kedudukan KPU dalam pelaksanaan pemilihan umum kepala daerah di Indonesia? (2) Bagaimanah konstitusionalitas Perppu Nomor 2 Tahun 2020 dan kaitannya dengan independensi KPU sebagai pelaksana Pemilukada di Indonesia?

\section{B. Metode Penelitian}

Metode yang digunakan dalam penelitian ini adalah metode penelitian hukum Yuridis Normatif (Legal Research) dengan pendekatan undang-undang (statute approach) dan pendekatan konseptual (conceptual approach). Melalui metode Yuridis Normatif, penelitian ini akan menelaah norma peraturan perundangundangan dan juga teori hukum yang berkaitan dengan judul penelitian.

Teknik pengumpulan bahan hukum yang digunakan dalam penelitian ini adalah studi kepustakaan atau library research. Teknik kepustakaan ini digunakan untuk memperoleh data sekunder yang diperoleh melalui pengumpulan bahan hukum primer dan bahan hukum sekunder melalui studi dokumen. Adapun bahan hukum primer yang digunakan di sini antara lain ialah:

1. Undang-Undang Dasar Negara Republik Indonesia 1945;

2. Undang-undang Nomor 32 Tahun 2004 tentang Pemerintahan Daerah;

$9 \quad$ Indonesia, Peraturan Pemerintah Pengganti Undang Undang Tentang Perubahan Ketiga Atas Undang Undang Nomor 1 Tahun 2015 Tentang Penetapan Peraturan Pemerintah Pengganti Undang-Undang Nomor 1 Tahun 2014 tentang Pemilihan Gubernur, Bupati, dan Walikota Menjadi Undang-Undang, Perppu No. 2 Tahun 2020, Lembaran Negara RI No. 128 Tahun 2020, Pasal 122A ayat (3).

10 Ibid., Pasal 201A ayat (2). 
3. Undang-Undang Nomor 1 Tahun 2015 tentang Penetapan Peraturan Pemerintah Pengganti Undang-Undang Nomor 1 Tahun 2014 tentang Pemilihan Gubernur, Bupati, dan Walikota menjadi Undang-Undang;

4. Undang-Undang Nomor 8 Tahun 2015 tentang Perubahan atas Undang-Undang Nomor 1 Tahun 2015 tentang Penetapan Peraturan Pemerintah Pengganti UndangUndang Nomor 1 Tahun 2014 tentang Pemilihan Gubernur, Bupati, dan Walikota menjadi Undang-Undang;

5. Undang-Undang Nomor 10 Tahun 2016 tentang Perubahan Kedua atas UndangUndang Nomor 1 Tahun 2015 tentang Penetapan Peraturan Pemerintah Pengganti Undang-Undang Nomor 1 Tahun 2014 tentang Pemilihan Gubernur, Bupati, dan Walikota menjadi Undang-Undang;

6. Peraturan Pemerintah Penggati UndangUndang Nomor 2 Tahun 2020 tentang Perubahan Ketiga atas Undang-Undang Nomor 1 Tahun 2015 tentang Penetapan Peraturan Pemerintah Pengganti UndangUndang Nomor 1 Tahun 2014 tentang Pemilihan Gubernur, Bupati, dan Walikota menjadi Undang-Undang;

7. Peraturan Komisi Pemilihan Umum Nomor 15 Tahun 2019.

Sedangkan bahan hukum sekunder meliputi publikasi terkait hukum yang tidak termasuk dalam dokumen-dokumen resmi. Publikasi tentang hukum antara lain yaitu: buku-buku teks, jurnal hukum, serta komentar atau pandangan ahli atas putusan pengadilan yang berkaitan dengan judul penelitian, yakni literatur seputar penyelenggaraan Pemilukada, pelaksanaan Pemilukada, serta kedudukan Perppu.

Selanjutnya, metode analisis yang digunakan dalam penelitian ini adalah metode analisis kualitatif. Adapun metode analisis kualitatif merupakan analisis data yang tidak menggunakan angka, melainkan memberikan gambaran-gambaran (deskripsi) dengan katakata atas temuan hasil penelitian.

\section{Pembahasan}

\section{Kedudukan KPU dalam Pelaksanaan Pemilukada serta Kewenangan Penundaan Pemilukada}

Pemilihan Umum bahwasanya merupakan instrumen penting dalam negara demokrasi yang menganut sistem perwakilan. ${ }^{11}$ Pemilihan Umum berfungsi sebagai media untuk menjaring para politisi yang akan mewakili rakyat dalam lembaga perwakilan maupun yang akan memimpin pemerintahan. ${ }^{12}$ Adapun dalam dimensi lain, Pemilu juga merupakan wadah yang memiliki fungsi sebagai sarana untuk menyampaikan hak-hak demokrasi rakyat. ${ }^{13}$ Dalam hal ini terlihat bahwa antara nilai-nilai demokrasi dan Pemilu memiliki sebuah keterkaitan yaitu bahwa demokrasi membutuhkan lembaga perwakilan dan pemerintahan untuk mewujudkan tujuannya sedangkan lembaga tersebut hanya dapat diwujudkan melalui pemilu. ${ }^{14}$

Pemilihan Umum selain dilaksanakan untuk memilih pelaksana tugas pemerintahan di tingkat nasional, juga dilaksanakan untuk

11 Miriam Budiardjo, Ilmu Politik, (Jakarta: Gramedia Pustaka Utama, 1982), hlm. $175 .$.

12 Mahfud MD, Politik Hukum di Indonesia, (Jakarta: RajaGrafindo Persada, 2014), hlm. 60.

13 Abdul Bari Azed, "Sistem Pemilihan Umum di Indonesia", Jurnal Hukum dan Pembangunan Volume 17 Nomor 2 (1987): 170.

14 Abdul Bari Azed dan Amir Makmur, Pemilu dan Partai Politik di Indonesia, (Jakarta: Pusat Studi Hukum Tata Negara Fakultas Hukum Universitas Indonesia, 2013), hlm. 11. 
memilih penyelenggara urusan pemerintahan daerah pada masing-masing tingkat daerah. ${ }^{15}$ Pemilihan Kepala Daerah dan DPRD sebagai penyelenggara urusan pemerintahan daerah yang dipilih melalui Pemilukada didasarkan pada amanat UUD NRI 1945. ${ }^{16}$ Oleh sebab itu, dapat dinilai bahwa penyelenggaraan mekanisme Pemilukada untuk memilih penyelenggara urusan pemerintahan daerah, khususnya kepala daerah telah berlandaskan pada prinsip negara hukum karena telah diatur di dalam konstitusi negara.

Untuk diketahui terlebih dahulu bahwa kepala daerah sebelum tahun 2005 dipilih melalui mekanisme pemilihan yang dilakukan oleh DPRD. ${ }^{17}$ Akan tetapi, sejak diberlakukannya Undang-Undang Nomor 32 Tahun 2004 tentang Pemerintahan Daerah, kepala daerah dipilih secara langsung oleh rakyat melalui Pemilukada. ${ }^{18}$ Pelaksanaan pemilihan kepala daerah secara langsung bahwasanya merupakan wujud pelaksanaan prinsip demokrasi dan kedaulatan rakyat yang juga sesuai dengan amanah Pasal 18 Ayat (4) UUD NRI 1945, dimana Gurbernur, Bupati, dan Walikota sebagai kepala pemerintahan daerah dipilih secara demokratis. ${ }^{19}$

Pemilukada sebagai mekanisme untuk memilih kepala daerah kemudian mendapatkan basis yuridisnya dalam pengaturan pada Undang Undang Nomor 1 Tahun 2015 Tentang Penetapan Peraturan Pemerintah Pengganti Undang-Undang Nomor 1 Tahun 2014 Tentang Pemilihan Gubernur, Bupati, dan Walikota menjadi Undang-Undang (selanjutnya disebut Undang Undang Pemilukada). Pada UndangUndang Pemilukada tersebut, diatur mengenai tata cara penyelenggaraan pemilukada, termasuk di dalamnya perihal organ penyelenggara pemilukada pada tiap daerah pemilihan.

Pemilukada yang mendapatkan basis yuridisnya sebagai sebuah perangkat hukum pada prinsipnya juga merupakan bagian dari subsistem hukum di Indonesia. Pemilukada sebagai kaidah hukum dalam sistem hukum Indonesia memerlukan sebuah organ atau yang dikenal sebagai struktur hukum yang berfungsi untuk melaksanakan ketentuan pengaturan yang telah diatur di dalam undang-undang yang dimaksud. ${ }^{20}$ Adapun keberadaan KPU beserta Komisi Pemilihan Umum di daerah (KPUD) merupakan struktur hukum yang dimaksud dalam penyelenggaraan Pemilukada sebagaimana diatur di dalam Undang Undang Pemilukada.

Penyelengaraan Pemilukada secara langsung kemudian menjadi tanggung jawab dan kewenangan KPU serta KPUD. ${ }^{21}$ Adapun

15 Ansori, "Legalitas Hukum Komisi Pemilihan Umum Daerah dalam Menyelenggarakan Pilkada", Jurnal Konstitusi Volume 14 Nomor 3 (2017): 565.

16 Ibid.

17 IRetno Saraswati, "Legalitas Hukum Komisi Pemilihan Umum Daerah dalam Menyelenggarakan Pilkada", Jurnal Dinamika Hukum 14 Nomor 2 (2014): 362.

18 Ali Marwan Hsb, "Pemilihan Kepala Daerah yang Demokratis Berdasarkan Putusan Mahkamah Konstitusi Nomor 97/ PUU-IX/2013", Jurnal Legislasi Indonesia Volume 13 Nomor 3 (2016): 229.

19 Ibid, hlm.227-228.

20 Dalam Teori Sistem Hukum yang dikemukakan oleh Lawrence M. Friedman, terdapat tiga komponene sistem hukum, yakni susbtansi hukum (legal substance), struktur hukum (legal structure), dan budaya hukum (legal culture). Adapun struktur hukum sendiri berkaitan dengan organ yang mebuat atau menjalankan suatu aturan, dalam Lindra Damela, "Tinjauan Sistem Hukum dalam Penerapan Peraturan Daerah Syari'ah di Tasikmalaya", Jurnal Ilmu Syari'ah dan Hukum Volume 50 Nomor 1 (2015): 263.

21 Indonesia, Undang-Undang Nomor 1 Tahun 2015 tentang Penetapan Peraturan Pemerintah Pengganti Undang- 
dalam hal ini KPU bertugas untuk menyusun serta menetapkan pedoman teknis untuk setiap tahapan Pemilihan yang kemudian dituangkan dalam bentuk Peraturan Komisi Pemilihan Umum (PKPU). Sedangkan mengenai perencanaan dan penetapan jadwal Pemilihan, hal tersebut ditetapkan oleh KPUD. Komisi Pemilihan Umum Daerah Provinsi berwenang untuk merencanakan dan menetapkan jadwal Pemilihan Gurbernur, sementara KPUD Kabupaten/Kota menetapkan jadwal Pemilihan Bupati dan Walikota. ${ }^{22}$

Secara kelembagaan, keberadaan KPU sebagai lembaga penyelenggara Pemilu memang tidak termasuk dalam bagian lembaga tinggi negara, bahkan nama KPU sendiri tidak ditentukan dalam konstitusi, melainkan dalam Undang-Undang Pemilu. Akan tetapi, konstitusi telah mengatur secara khusus mengenai pembentukan lembaga penyelenggara Pemilu yang dirumuskan secara tegas dalam Pasal 22E UUD NRI 1945. ${ }^{23}$ Pasal 22E Ayat (5) UUD NRI 1945 mengatur bahwa: "Pemilihan umum diselenggarakan oleh suatu komisi pemilihan umum yang bersifat nasional, tetap, dan mandiri" ${ }^{24}$. Adapun selanjutnya Pasal 22E Ayat (6) UUD NRI 1945 mengatur bahwa ketentuan lebih lanjut mengenai keberadaan komisi pemilihan umum akan diatur secara khusus dalam undang-undang. Undang-Undang ini lah kemudian yang akan memberi wewenang kepada KPU sebagai lembaga penyelenggara Pemilu dan membentuk PKPU sebagai aturan teknis dalam penyelenggaraan Pemilu.

Berdasarkan ketentuan dalam konstitusi tersebut, terlihat bahwa kedudukan KPU sebagai lembaga penyelenggara Pemilu memiliki arti penting yang keberadaanya telah dijamin dan dilindungi secara konstitusional dalam UUD NRI 1945. ${ }^{25}$ Atas hal tersebut, keberadaan lembaga KPU dapat dikatakan sebagai lembaga negara yang memiliki constitutional importance. Artinya, meski tidak diatur secara eksplisit dalam konstitusi, namun KPU memiliki kedudukan yang sama penting dengan lembaga negara yang diatur secara ekspilsit dalam konstitusi. ${ }^{26}$ Selain itu, kedudukan KPU sebagai lembaga yang memiliki constitutional importance bahwasanya juga didukung dengan sifat kemandirian lembaga yang mengharuskan KPU untuk bersifat independen. Untuk itu, dalam menjalankan kewenangan yang bersumber dari undang-undang, KPU tidak boleh berada dalam pengaruh individu, golongan, partai politik, hingga pemerintah, guna mewujudkan netralitas dalam penyelenggaraan Pemilu di Indonesia ${ }^{27}$.

Kewenangan yang diperoleh KPU dalam menjadi penyelenggara Pemilu tingkat nasional tersebut juga tidak dapat terlepas

Undang Nomor 1 Tahun 2014 tentang Pemilihan Gubernur, Bupati, dan Walikota menjadi Undang-Undang, Lembaran Negara RI No.23 Tahun 2015, Pasal 8 Ayat (1).

22 Ansori, Jazim Hamidi, dan Muhammad Ali Safa'at, "Kedudukan Hukum Komisi Pemlihan Umum Daerah dalam Menyelengarakan Pemilihan Kepala Daerah Pasca Putusan MK Nomor 97/PUU-XI/2013", Jurnal Mahasiswa Fakultas Hukum (2016): 8.

23 Jimly Asshiddiqie, Perkembangan dan Konsolidasi Lembaga Negara Pasca Reformasi, (Jakarta: Sekretariat Jenderal dan Kepaniteraan Mahkamah Konstitusi), hlm.235.

24 Indonesia, Undang-Undang Negara Republik Indonesia Tahun 1945, Pasal 22E Ayat (5).

25 Jimly Asshiddiqie, Perkembangan dan Konsolidasi..., hlm.37.

$26 \mathrm{Ibid}, \mathrm{hlm} .25$.

27 Fajar Alfyana, "KPU dan Konsolidasi Demokrasi: Studi Terhadap Independensi KPU Kota Makassar", Jurnal Vox Populi Volume 2 Nomor 2 (2019):134. 
dalam hubungannya dengan penyelenggaraan Pemilihan di tingkat daerah. Oleh sebab itu, Undang-Undang Nomor 22 Tahun 2007 tentang Penyelenggaraan Pemilihan Umum telah mengatur mengenai pembentukan KPU pada tingkat provinsi dan kabupaten/kota. ${ }^{28}$ Adapun keberadaan Komisi Pemilihan Umum di tingkat daerah ini (KPUD) dimaksudkan sebagai pelaksana Pemilihan di tingkat Provinsi dan Kabupaten/Kota yang merupakan bagian dari KPU. Dalam hal ini KPUD mengemban wewenang dalam pelaksanaan Pemilukada serentak baik pada tingkat provinsi maupun kabupaten/kota, termasuk dalam pelaksanaan Pemilukada 2020 yang akhirnya harus mengalami penundaan.

Pengaturan terkait penyelenggaraan Pemilukada 2020 sebagaimana di kemudian hari memunculkan masalah terkait penyelenggaraannya telah diatur sebelumnya pada Undang-Undang Nomor 10 Tahun 2016 Tentang Perubahan Kedua atas Undang-Undang Nomor 1 Tahun 2015 Tentang Penetapan Peraturan Pemerintah Pengganti UndangUndang Nomor 1 Tahun 2014 Tentang Pemilihan Gubernur, Bupati, dan Walikota menjadi Undang-Undang. Pada ketentuan Pasal 201 Ayat (6) Undang Undang tersebut disebutkan bahwa: "Pemungutan suara serentak Gubernur dan Wakil Gubernur, Bupati dan Wakil Bupati, serta Walikota dan Wakil Walikota hasil pemilihan tahun 2015 dilaksanakan pada bulan September tahun 2020". ${ }^{29}$ Lebih lanjut terkait jadwal tahapan persiapan dan penyelenggaraanya telah disebutkan dalam Lampiran PKPU Nomor 15 Tahun 2019 Tentang
Tahapan, Program Dan Jadwal Penyelenggaraan Gubernur dan Wakil Gubernur, Bupati dan Wakil Bupati, Dan/atau Wali Kota dan Wakil Wali Kota Tahun 2020 dimana tahap pemungutan suara dilaksanakan pada 23 September 2020. ${ }^{30}$ Akan tetapi mengingat adanya penyebaran Pandemi Covid-19 yang terjadi saat ini, maka pelaksanaan Pemilukada tahun 2020 harus mengalami penundaan.

Sebagaimana telah dijelaskan sebelumnya, bahwa Presiden telah mengeluarkan Keputusan Presiden (Keppres) Nomor 11 Tahun 2020 tentang Penetapan Kedaruratan Kesehatan Masyarakat Corona Virus Disease 2019 (Covid 19). Adanya Keppres tersebut kemudian melahirkan Peraturan Pemerintah Nomor 21 Tahun 2020 tentang Pembatasan Sosial Berskala Besar (PSBB) sebagai bentuk respon terhadap penyebaran Pandemi Covid-19 sekaligus pelaksanaan kekarantinaan kesehatan sebagaimana yang diatur dalam UndangUndang Nomor 6 Tahun 2018 tentang Karantina Kesehatan. Selanjutnya Presiden merubah status kedararutan kesehatan Pandemi Covid-19 menjadi bentuk bencana non-alam yang dituangkan di dalam Keppres Nomor 12 Tahun 2020 tentang Penetapan Bencana Non Alam Penyebaran Covid-19 sebagai Bencana Nasional. Adanya penetapan status bencana non alam dan pemberlakuan PSBB ini kemudian berpengaruh pada penundaan pelaksanaan Pemilukada 2020.

Terkait pengaturan mengenai penundaan pemilukada di dalam Undang Undang Pemilukada pada dasarnya telah diatur di dalam

28 Indonesia, Undang-Undang Nomor 22 Tahun 2007 tentang Pemilihan Umum, Lembaran Negara RI No. Tambahan Lembaran Negara RI No.59 Tahun 2007, Tambahan Lembaran Negara No.2791, Pasal 4.

29 Ibid, Pasal 201 Ayat (6).

30 Lampiran Peraturan Komisi Pemilihan Umum Nomor 15 Tahun 2019 tentang Tahapan, Program, dan Jadwal Penyelenggaraan Pemilihan Gurbernur dan Wakil Gurbernur, Bupati dan Wakil Bupati, dan/atau Walikota dan Wakil Walikota Tahun 2020. 
Pasal 120 dan 121 Undang-Undang Pemilukada. Pasal 120 Undang-Undang Nomor 1 Tahun 2015 mengatur bahwa: "Dalam hal sebagian atau seluruh wilayah Pemilihan terjadi kerusuhan, gangguan keamanan, bencana alam, atau gangguan lainnyayangmengakibatkan sebagian tahapan penyelenggaraan Pemilihan tidak dapat dilaksanakan, maka dilakukan Pemilihan Ianjutan. $^{31}$ Sedangkan Pasal 121 mengatur bahwa: "Dalam hal di suatu wilayah Pemilihan terjadi bencana alam, kerusuhan, gangguan keamanan, dan/atau gangguan lainnya yang mengakibatkan terganggunya seluruh tahapan penyelenggaraan Pemilihan maka dilakukan Pemilihan susulan"32. Secara prinsip dalam hal ini penundaan Pemilukada dimungkinkan untuk dilaksanakan apabila hal tersebut memenuhi kriteria penundaan pemilukada sebagaimana yang dimaksud di dalam Pasal 120 dan Pasal 121 Undang Undang Pemilukada.

Penyebaran Pandemi Covid-19 sebagaimana yang telah ditetapkan melalui Keppres Nomor 12 Tahun 2020 tentang Penetapan Bencana Non Alam Penyebaran Covid-19 sebagai Bencana Nasional dapat dinilai sebagai bentuk gangguan yang memenuhi syarat penundaan Pemilukada. Terkait keberadaan gangguan yang berpengaruh terhadap penyelenggaraan Pemilukada maka penundaan Pemilukada juga akan ditetapkan dengan pemilihan lanjutan dan pemilihan susulan sebagaimana ketentuan pada Undang Undang Pemilukada. Pemilihan lanjutan dilakukan dalam hal terjadi hambatan pada sebagian atau seluruh wilayah pemilihan, sehingga perlu dilakukan Pemilihan lanjutan yang dimulai dari tahap penyelenggaraan Pemilihan yang terhenti, sementara Pemilihan susulan dilakukan pada suatu wilayah dan dilakukan untuk seluruh tahapan penyelenggaraan Pemilihan. ${ }^{33}$

Berdasarkan hal tersebut, dapat dilihat bahwasanya Undang-Undang Pemilukada telah mengenal istilah penundaan pelaksanaan Pemilukada dan keberadaan pemilihan lanjutan serta pemilihan susulan. Akan tetapi, penundaan yang diatur dalam Undang-Undang Pemilukada masih bersifat pendekatan lokal, sehingga tidak mampu untuk mengakomodir kondisi yang disebabkan oleh penyebaran Pandemi Covid-19 yang berskala nasional. Selain itu, mekanisme penundaan pelaksanaan Pemilukada yang dilanjutkan melalui skema Pemilukada lanjutan dan skema Pemilukada susulan hanya dapat dilaksanakan melalui usul Panitia Pemilihan Kecamatan (PPK) kepada KPU Kabupaten/Kota dan/atau KPU Provinsi dengan tahapan yang berjenjang. ${ }^{34}$

Ketiadaan pengaturan yang mengakomodir penundaan Pemilukada secara serentak di lebih dari satu daerah pemilihan menyebabkan adanya kekosongan hukum dalam penyelenggaraan Pemilukada serentak 2020 di Indonesia. Adapun jika mengacu pada kelembagaan KPU berdasarkan UUD NRI 1945, maka KPU selaku institusi yang mandiri hanya dapat melaksanakan tugasnya berdasarkan perintah

31 Indonesia, Undang-Undang Nomor 1 Tahun 2015 tentang Penetapan Peraturan Pemerintah Pengganti UndangUndang Nomor 1 Tahun 2014 tentang Pemilihan Gubernur, Bupati, dan Walikota menjadi Undang-Undang, Lembaran Negara RI No.23 Tahun 2015, Pasal 120.

32 Ibid, Pasal 121 Ayat (1)

33 Ibid, Pasal 120 dan 121 Ayat (2)

34 Menurut Undang-Undang Pemilukada, kewenangan untuk menetapkan penundaan Pemilukada berada pada KPU Provinsi maupun KPU Kabupaten/Kota. Hal ini membentuk alur birokrasi yang sangat menyulitkan dalam hal penundaan Pemilukada yang seharusnya dapat langsung dilaksanakan oleh KPU. 
dari undang-undang yang mengaturnya. Hal ini merupakan konsekuensi dari kedudukan Indonesia sebagai negara hukum yang berarti bahwa setiap penyelenggaraan urusan pemerintahan haruslah berdasarkan pada konstitusi dan peraturan perundang-undangan yang berlaku. ${ }^{35}$ Dalam hal ini, sekalipun KPU memiliki kewenangan untuk membentuk PKPU, namun tidak ada pengaturan dalam undangundang yang memberi kewenangan pada KPU untuk menunda pelaksanaan Pemilukada secara serentak. Oleh sebab itu, dibutuhkan peraturan perundang-undangan sebagai payung hukum yang dapat mengakomodir kewenangan KPU dalam melakukan penundaan Pemilukada serentak di Indonesia.

\section{Konstitusionalitas Perppu Pemilukada Dan Kaitannya Dengan Independensi KPU}

Ketiadaan instrumen hukum yang mengatur mengenai penundaan Pemilukada berskala nasional termasuk ketiadaan kewenangan bagi KPU untuk menetapkan tanggal pemilukada pasca-penundaan, membuat pemerintah mengambil inisiatif untuk mengesahkan Perppu Nomor 2 Tahun 2020 untuk mengisi kekosongan hukum yang ada. Pembentukan Perppu sebagai peraturan perundang-undangan setingkat Undang Undang yang pembentukannya diinisiasi oleh Presiden pada akhirnya ditempuh oleh pemerintah akibat kedaruratan yang ada. ${ }^{36}$

Keberadaan Perppu sebagai produk hukum pengganti undang-undang yang kedudukannya setingkat dengan undang-undang bahwasanya dilandasi oleh ketentuan dalam Pasal 12 dan Pasal 22 UUD NRI 1945. Ketentuan Pasal 12 UUD NRI 1945 mengatur bahwa: "Presiden menyatakan keadaan bahaya. Syarat-syarat dan akibatnya keadaan bahaya ditetapkan dengan undangundang". Sedangkan Pasal 22 Ayat (1) UUD NRI 1945 mengatur bahwa: "Dalam hal ihwal kegentingan yang memaksa, Presiden berhak menetapkan peraturan pemerintah sebagai pengganti undang-undang". Berdasarkan pengaturan pada kedua pasal tersebut, dapat kita lihat bahwasanya terdapat dua tipe Perppu. Pertama yang diterbitkan dalam hal keadaan bahaya, dan yang kedua Perppu sebagai undangundang biasa dan bersifat sementara yang diterbitkan karena adanya hal ihwal kegentingan memaksa. ${ }^{37}$

Untuk diketahui terlebih dahulu bahwa kedudukan Presiden dalam ketatanegaraan di Indonesia dapat dilihat sebagai dua sisi, yaitu sebagai kepala pemerintahan sekaligus sebagai kepala negara. ${ }^{38} \mathrm{Hal}$ tersebut tidak dapat dilepaskan dari sistem pemerintahan di Indonesia yang menganut sistem presidensil dimana pengaruh Presiden sangat kuat dalam sebuah negara. ${ }^{39}$ Kewenangan Presiden yang besar dalam sistem presidensil harus selalu dilihat dalam konteks bahwa Presiden memiliki tanggung jawab konstitusional sebagai kepala negara untuk menjaga kelancaran urusan

35 Ni'matul huda, Negara Hukum dan Demokrasi \& Judical Review, (Yogyakarta: UII Press, 2005), hlm.19.

36 Jimly Asshiddiqie, Hukum Tata Negara Darurat, (Jakarta: Raja Grafindo Persada, 2007), hlm. 303.

37 Jimly Asshiddiqie, "Dua tipe Perppu" (paper disampaikan pada Webinar Perkembangan Hukum Tata Negara Darurat di Indonesia, Jakarta, 30 April 2020).

38 Mohammad Hudi, "Kedudukan Dan Tanggung Jawab Presiden Dalam Sistem Presidensial Di Indonesia", Mimbar Yustisia volume 2 Nomor 2 (2018): 185.

39 Sistem Presidensil memiliki empat karakteristik yaitu bahwa sistem ini menganut pemisahan kekuasaan, kabinet dan Presiden yang tidak bertanggung jawab terhadap parlemen, Presiden tidak dapat membubarkan parlemen, dan dipilih melalui dewan pemilih. Ahmad Yani, "Sistem Pemerintahan Indonesia: Pendekatan Teori Dan Praktek Konstitusi Undang Undang Dasar 1945", Jurnal Legislasi volume 15 Nomor 2 (2018): 60. 
penyelenggaraan kekuasaan negara. ${ }^{40}$

Korelasi antara Perppu dan sistem pemerintahan presidensil yang diterapkan di Indonesia dapat dilihat dari kenyataan bahwa Presiden selaku lembaga eksekutif dianggap paling mengetahui dan memiliki akses terluas dalam memperoleh informasi yang paling dibutuhkan dalam proses pembentukan undang-undang. ${ }^{41}$ Selain itu, pembentukan Perppu oleh Presiden juga didasarkan untuk menjaga terjaminnya keselamatan negara yang mengharuskan pemerintah untuk bertindak secara lekas dan cepat. Lebih lanjut, tindakan secara lekas dan cepat tersebut dipengaruhi oleh adanya kegentingan atau keadaan darurat yang mengharuskan Presiden untuk mengambil langkah luar biasa dalam proses pembentukan hukum. ${ }^{42}$

Perihal keadaan bahaya pada tataran teori sangat lekat dengan keberadaan "the state of emergency". Adanya klausul "the state of emergency" atau keadaan darurat dalam suatu negara, memberi kewenangan khusus kepada Presiden sebagai pemegang kekuasaan pemerintahan atau kepada otoritas konstitusional lainnya untuk mendeklarasikan atau menetapkan berlakunya dan berakhirnya suatu keadaan darurat dengan menerbitkan aturan-aturan yang bersifat sementara selama dalam keadaan darurat dengan menangguhkan berbagai jaminan hak dan kebebasan, bahkan juga menangguhkan berbagai proses penegakan hukum. Hal ini perlu disadari semata-mata dilakukan dalam rangka penyelematan kepentingan seluruh rakyat. ${ }^{43}$

Berbeda dengan rezim negara dalam keadaan darurat, penafsiran mengenai Pasal 22 UUD NRI 1945 mengenai hal ihwal kegentingan memaksa lebih didasarkan pada ketiadaan suatu produk hukum atau kekosongan hukum yang terjadi. Hal ini sebagaimana tertuang dalam Putusan Mahkamah Konstitusi (MK) Nomor 138/PUU-VII/2009, dimana MK menetapkan tiga parameter atau tiga syarat adanya "kegentingan memaksa" bagi Presiden untuk menerbitkan Perppu, yakni sebagai berikut: ${ }^{44}$

1. Adanya keadaan yaitu kebutuhan mendesak untuk menyelesaikan masalah hukum secara cepat berdasarkan Undang-Undang;

2. Undang-Undang yang dibutuhkan tersebut belum ada sehingga terjadi kekosongan hukum, atau ada Undang-Undang tetapi tidak memadai;

Kekosongan hukum tersebut tidak dapat diatasi dengan cara membuat Undang-Undang secara prosedur biasa karena akan memerlukan waktu yang relatif lama sedangkan keadaan yang mendesak tersebut perlu kepastian untuk diselesaikan.

Jika mengacu pada parameter keadaan darurat sebagai syarat pembentukan Perpu dapat dikatakan bahwa lahirnya Perppu Nomor 2 Tahun 2020 mengenai perubahan atas Undang-Undang Pemilukada dikarenakan terjadinya kekosongan hukum terkait pengaturan kewenangan lembaga yang berhak untuk menetapkan jadwal penundaan Pemilukada. Selain itu pengaturan mengenai jadwal penyelenggaraan pemungutan

\footnotetext{
40 Zulbaidah dan Zulkarnaen, "Pertanggungjawaban Presiden di Indonesia Berdasarkan UUD 1945", Varia Hukum Volume 1 Nomor 1 (2019): 82.

41 Mohammad Zamroni, "Kekuasaan Presiden Dalam Mengeluarkan Perppu", E-Jurnal Peraturan (2015): 12.

42 Ni'matul Huda, Politik Ketatanegaraan Indonesia, (Yogyakarta: FH UII Press, 2003), hIm. 140.

43 Jimly Asshiddiqie, "Diktator Konstitusional dan Hukum Pengecualian" (paper disampaikan pada Webinar Perkembangan Hukum Tata Negara Darurat di Indonesia, Jakarta, 30 April 2020).

44 Republik Indonesia, Putusan Mahkamah Konstitusi Nomor 138/PUU-VII/2009.
} 
suara pada Pemilukada 2020 yang semula dijadwalkan pada September 2020 dianggap menjadi masalah hukum ketika pelaksanaanya tidak dimungkinkan. Adapun hal ini tidak dapat diatasi dengan cara membentuk undang-undang dengan prosedur biasa karena memerlukan tahapan yang panjang dan waktu yang relatif lama, sehingga pembentukan Perppu merupakan solusi untuk mengatur mengenai penjadwalan kembali penyelenggaraan Pemilukada 2020. Selain itu, pengaturan kembali mengenai jadwal pelaksanaan pemungutan suara Pemilukada 2020 juga dianggap sebagai kepentingan mendesak yang memerlukan kepastian hukum untuk penyelesaiannya.

Keberadaan Perppu Nomor 2 Tahun 2020 ini bahwasanya juga didukung oleh DPR sebagai lembaga pembentuk undang-undang serta KPU dan Bawaslu sebagai lembaga yang bertanggung jawab atas penyelenggaraan Pemilukada. Pada Rapat Dengar Pendapat (RDP) Komisi 2 DPR dengan Menteri Dalam Negeri (Mendagri), KPU, dan juga Badan Pengawas Pemilu (Bawaslu) tanggal 14 April 2020, Mendagri selaku pihak Pemerintah mengusulkan agar tahapan pelaksanaan Pemilukada 2020 diundur menjadi tanggal 9 Desember 2020, dan hal ini kemudian disepakati oleh DPR, KPU, dan Bawaslu. Selain itu, keempat lembaga tersebut juga mengusulkan agar pembentukan Perppu dapat segera diterbitkan karena Undang-Undang Pemilukada yang ada saat ini tidak mampu untuk mengakomodor situasi penyebaran Pandemi Covid-19. ${ }^{45}$
Berdasarkan hal-hal tersebut, maka dapat dikatakan bahwasanya pembentukan Perppu memang menjadi hal yang konstitusional dan juga dibutuhkan untuk mengatasi permasalahan penundaan dan penetapan jadwal pemungutan suara Pemilukada 2020. Adapun penetapan tanggal 9 Desember sebagai jadwal pemungutan suara pada Pemilukada 2020 memang sudah diusulkan sebelumnya dalam RDP antara Komisi 2 DPR dengan Mendagri, KPU, dan Bawaslu. Namun, kehadiran Perppu tetap dibutuhkan untuk memberi kepastian hukum yang mengikat terkait penundaan pelaksanaan pemungutan suara pada Pemilukada 2020 dan juga untuk mengatur mengenai kewenangan lembaga yang berhak untuk menetapkan penundaan jadwal tersebut.

Keberadaan Perppu Nomor 2 Tahun 2020 kemudian memberi kewenangan kepada KPU untuk menetapkan penundaan tahapan pelaksanaan Pemilihan serentak lanjutan melalui Keputusan KPU yang telah mendapatkan persetujuan bersama antara KPU, Pemerintah, dan DPR, yang mana hal ini diatur dalam Pasal 122 A Perppu Nomor 2 Tahun 2020. ${ }^{46}$ Adapun ketentuan lebih lanjut mengenai tata cara dan waktu pelaksanaan Pemilihan serentak diatur secara teknis melalui Peraturan KPU. ${ }^{47}$

Beberapa pengaturan lainnya dalam Perppu Nomor 2 Tahun 2020 ialah penambahan frasa "bencana non-alam" pada Pasal 120 Ayat (1). Jika sebelumnya Undang-Undang Pemilukada hanya mengatur bahwa pelaksanaan Pemilihan dapat ditunda apabila terjadi kerusuhan,

45 Kesimpulan Rapat Kerja Dan Rapat Dengar Pendapat Komisi II DPR RI Dengan Menteri Dalam Negeri, Komisi Pemilihan Umum, dan Badan Pengawas Pemilu pada 14 April 2020.

46 Indonesia, Peraturan Pemerintah Pengganti Undang-Undang tentang Perubahan Ketiga Atas Undang-Undang Nomor 1 Tahun 2015 tentang Penetapan Peraturan Pemerintah Pengganti Undang-Undang Nomor I Tahun 2014 Tentang Pemilihan Gubernur, Bupati, Dan Walikota Menjadi Undang-Undang, Tambahan Lembaran Negara No. 6512, Pasal 122 A Ayat (1).

47 Ibid, Pasal 122 A Ayat (3). 
gangguan keamanan, bencana alam, dan gangguan lainnya yang dianggap menjadi faktor penghambat penyelenggaraan Pemilukada, maka adanya Perppu Nomor 2 Tahun 2020 ini telah mengklasifikasikan bencana non alam sebagai bagian dari keadaan yang dapat menghambat pelaksanaan tahapan Pemilukada. Adapun dalam hal ini Pandemi Covid-19 merupakan bencana non alam yang dapat menghambat pelaksanaan tahapan Pemilukada 2020. Selain itu, Perppu Nomor 2 Tahun 2020 juga telah memberi ruang untuk menjadwalkan kembali pelaksanaan pemungutan suara serentak apabila pelaksanaan pada 9 Desember 2020 tidak dimungkinkan akibat masih adanya penyebaran Pandemi Covid-19. Penundaan dan penjadwalan kembali pelaksanaan pemungutan suara pada Pemilukada 2020 ini tentu saja juga mengubah seluruh tahapan pelaksanaan Pemilukada lainnya, dan membutuhkan Peraturan KPU untuk menyusunnya kembali.

Berdasarkan hal-hal tersebut, dapat dilihat bahwa kehadiran Perppu Nomor 2 Tahun 2020 telah menjadi payung hukum bagi keberlangsungan penyelenggaraan Pemilukada di tengah penyebaran Pandemi Covid-19 yang terjadi saat ini. Penyebaran Pandemi Covid-19 bahwasanya telah berdampak pada seluruh sektor kehidupan negara, termasuk dalam hal penyelenggaraan Pemilu sebagai bagian dari pelaksanaan prinsip demokrasi. Adapun penundaan pelakanaan Pemilu baik di tingkat nasional maupun di tingkat daerah tidak hanya terjadi di Indonesia. Sebagaimana hasil riset dari
Institute for Democracy and Electoral Assistance (IDEA), bahwa per 23 April 2020 telah terdapat 51 negara yang menunda penyelenggaraan Pemilu 2020. ${ }^{48}$

Pemberlakuan Perppu Nomor 2 Tahun 2020 sangat erat kaitannya dengan konsep independensi penyelenggaraan Pemilukada di Indonesia. Konsep independensi yang dimaksud tidak luput dari pengaturan mengenai mekanisme pemilihan umum sebagaimana yang diamanatan oleh Pasal 22E Ayat (5) UUD NRI 1945. Adapun keberadaan Pasal 22E Ayat (5) UUD NRI 1945 pada hakikatnya hendak menjelaskan perihal KPU yang merupakan sebuah komisi yang dibentuk dan bekerja secara independen untuk menyelenggarakan Pemilu di Indonesia. ${ }^{49}$

Kendati konsep independensi penyelenggaraan Pemilu melalui pembentukan KPU merupakan sebuah sistem pemilu untuk memilih Presiden dan Wakil Presiden, Anggota DPR, Anggota DPD, dan Anggota DPRD, namun hubungan hierarkis antara KPU dengan KPUD sebagai penyelenggara Pemilukada di daerah menunjukan adanya keseragaman pengaturan mengenai sistem kepemiluan baik nasional maupun daerah. Hubungan antara KPU dan KPUD (Provinsi maupun Kabupaten/Kota) dapat dilihat dari ketentuan pada Pasal 9 Ayat (1) Undang Undang Nomor 7 Tahun 2017 Tentang Pemilihan Umum (selanjutnya disebut Undang Undang Pemilu) yang menjelaskan bahwa antara KPU, KPU Provinsi dan KPU Kabupaten/ Kota dipersatukan oleh hubungan yang bersifat

48 Pontianak Post, "Belajar dari Suksesnya Korea Selatan Gelar Pemilu Saat Pandemi", https://pontianakpost.co.id/ belajar-dari-suksesnya-korea-selatan-gelar-pemilu-saat-pandemi/ (diakses 12 Juni 2020).

49 Menurut William F. Fox. Jr. untuk melihat apakah sebuah komisi negara dikatakan independen atau tidak, dapat dilihat apabila terdapat ketentuan dan penyebutan yang tegas di dalam sebuah Undang Undang. Titik Triwulan T. dan H. Ismu Gunadi Widodo, Hukum Tata Usaha Negara dan Hukum Acara Peradilan Tata Usaha Negara Indonesia, (Jakarta: Kencana Prenada Media Group, 2003), hlm. 118. 
hierarkis. ${ }^{50}$ Adapun makna hierarkis menurut Hamid S. Attamimi dapat dimaknai sebagai wujud piramida, yaitu yang paling dasar adalah sebuah acuan untuk dikembangkan namun perkembangan yang ada tidak dibolehkan keluar dari acuan dasar tersebut. ${ }^{51}$

Hierarkisme hubungan antara KPU dan KPUD juga diatur di dalam PKPU Nomor 8 Tahun 2019 Tentang Tata Kerja Komisi Pemilihan Umum, Komisi Pemilihan Umum Provinsi, Dan Komisi Pemilihan Umum Kabupaten/Kota. Peraturan tersebut mengatur secara tegas konsep independensi KPU dan KPUD yang mana kedua lembaga tersebut merupakan lembaga yang dalam menjalankan tugasnya terbebas dari pengaruh pihak manapun. ${ }^{52}$

Penafsiran mengenai hubungan antara KPU dan KPUD sempat menjadi perdebatan tersendiri yang ditandai dengan keluarnya putusan Mahkamah Konstitusi Republik Indonesia Nomor 97/PUU-XI/2013. Pada putusan MK tersebut, Majelis Hakim menafsirkan bahwa Pemilukada merupakan rezim hukum Pemerintahan Daerah sebagaimana diatur di dalam Pasal 18 UUD NRI 1945, bukan rezim hukum Pemilu sebagaimana di atur di dalam Pasal 22E UUD NRI $1945 .{ }^{53}$ Akan tetapi, sekalipun Putusan MK tersebut memisahkan antara Pemilu dan Pemiluda namun Putusan tersebut tidak memberikan penilaian terhadap kedudukan KPU terhadap KPUD dalam kelembagaan negara di Indonesia.

Pada kenyataannya walaupun Pemilu dan Pemilukada memiliki perbedaan rezim hukum sesuai dengan Putusan MK Nomor 97/PUU$\mathrm{XI} / 2013$ namun pengaturan mengenai KPU dan KPUD bertanggung jawab secara bersama dalam penyelenggaraan Pemilukada tetap diatur di dalam Undang Undang Pemilukada. ${ }^{54}$ Selain itu, KPU menurut Undang-Undang Pemilukada juga dibekali dengan tugas dan wewenang untuk memfasilitasi KPUD dalam menjalankan tugasnya. ${ }^{55} \mathrm{Hal}$ ini bermakna bahwa kedua lembaga tersebut adalah lembaga independen yang berwenang terhadap penyelenggaraan pemilukada di Indonesia.

Independensi penyelenggaraan Pemilu oleh KPU dan KPUD dalam menyelenggarakan Pemilukada juga dapat dilihat dari beberapa Putusan Mahkamah Konstitusi yan diantaranya adalah Putusan MK Nomor 072-073/PUUII/2004, Putusan MK Nomor 81/ PUU-IX/2011, dan Putusan MK Nomor 92/PUU-XIV/2016. Ketiga Putusan MK tersebut pada substansinya merupakan penafsiran MK terhadap pentingnya independensi bagi KPU dan KPUD dalam menjalankan tugasnya. Adapun ketiga Putusan MK tersebut dapat dijelaskan secara singkat sebagai berikut:

50 The negotiation "ASEAN, the declaration on conduct, and the South China Sea", LESZEK BUSZYNSKI, Contemporary Southeast Asia. Vol.25,No.3(dec.2003),pp.343-362, httpss://www.jstor.org/stable/25798652.

51 Jimly Asshiddiqie dan M. Ali Safa'at, Teori Hans Kelsen Tentang Hukum, (Jakarta: Mahkamah Konstitusi Republik Indonesia, 2006), hlm. 171.

52 Indonesia, Peraturan Komisi Pemilihan Umum Republik Indonesia Tentang Tata Kerja Komisi Pemilihan Umum, Komisi Pemilihan Umum Provinsi, Dan Komisi Pemilihan Umum Kabupaten/Kota, PKPU No. 8 Tahun 2019, B.N.R.I. No. 320 Tahun 2019, Pasal 5 Ayat (5)..

53 Putusan MK No. 97/PUU-XI/2013 berimplikasi pada mekanisme penyelesaian sengketa Pemilukada yang awalnya diatur sebagai kewenangan MK, namun beralih sebagai kewenangan Mahkamah Agung sejak pemberlakuan Putusan MK tersebut. Republik Indonesia, Putusan Mahkamah Konstitusi Republik Indonesia Nomor 97/PUU-XI/2013.

54 Indonesia, Undang Undang Tentang Penetapan Peraturan Pemerintah Pengganti Undang-Undang Nomor 1 Tahun 2014 tentang Pemilihan Gubernur, Bupati, dan Walikota Menjadi Undang-Undang, Undang-Undang Nomor 1 Tahun 2015, Lembaran Negara RI No. 245 Tahun 2014, Pasal 8 ayat (1).

55 Ibid, Pasal 9. 
a. Putusan MK Nomor 072-073/PUUII/2004 dalam substansinya memperkuat independensi KPUD dalam hal penghapusan pertanggung jawaban KPUD terhadap DPRD. Beberapa pengaturan yang dihapus oleh MK terkait pertanggung jawaban KPUD terhadap DPRD adalah ketentuan mengenai frasa KPUD yang bertanggung jawab terhadap DPRD, pengaturan mengenai dana Pemilukada yang seharusnya juga dibebankan kepada APBN, dan penghapusan kewenangan DPRD dalam membatalkan pasangan calon peserta Pemilukada yang melakukan pelanggaran politik uang. ${ }^{56}$

b. Putusan MK Nomor 81/ PUU-IX/2011 dalam substansinya memperkuat independensi KPU dalam hal potensi terjadinya konflik kepentingan antara KPU dengan Partai Politik yang dapat terjadi oleh karena keanggotaan KPU yang memungkinkan diisi oleh mantan anggota Partai Politik tertentu. Putusan MK ini dalam substansinya mengatur mengenai batas waktu pengunduran diri dari partai politik bagi seseorang yang hendak mendaftarkan diri sebagai calon anggota KPU dan Bawaslu, yakni sekurangkurangnya adalah 5 (lima) tahun. ${ }^{57}$

c. Putusan MK Nomor 92/PUU-XIV/2016 dalam substansinya memperkuat independensi KPU dalam hal pembentukan PKPU yang terbebas dari intervensi DPR dan Pemerintah. Putusan MK ini dalam substansinya membatalkan frasa "yang keputusannya bersifat mengikat" dari pengaturan mengenai kewajiban KPU untuk mengkonsultasikan PKPU yang dibuatnya melalu Rapat Dengar Pendapat dan baru dapat menetapkan PKPU tersebut setelah mendapatkan persetujuan DPR dan Pemerintah dengan keputusan yang bersifat mengikat. ${ }^{58}$

Ketiga Putusan MK sebagaimana yang telah disebutkan dapat diartikan sebagai pemahaman terhadap makna independensi penyelenggaraan Pemilu oleh KPU dan KPUD. Perlu disadari bahwa independensi yang diharapkan oleh UUD NRI 1945 tidak hanya dimaknai sebagai kebebasan KPU dan KPUD dari intervensi peserta pemilu saja, namun juga kebebasan dari potensi intervensi kekuasaan, baik DPR maupun Pemerintah dalam penyelenggaraan Pemilukada. ${ }^{59}$ Ada pun bentuk potensi bentuk intervensi yang mungkin dapat terjadi salah satunya dengan pemberlakuan produk legislasi, baik yang diinisiasi oleh DPR maupun yang diinisiasi oleh Pemerintah.

Pembentukan Perppu sebagaimana yang telah dijelaskan sebelumnya merupakan kewenangan Pemerintah dalam membentuk peraturan untuk mengganti sebuah Undang Undang yang memiliki basis konstitusional menurut UUD NRI 1945. Pada kaitannya dengan pemberlakuan Perppu Nomor 2 Tahun 2020 Presiden sedang menjalankan tugasnya sebagai pejabat tertinggi dalam pemerintahan negara Indonesia untuk mencegah terjadinya kekosongan hukum di masyarakat. Kekosongan hukum itu sendiri adalah suatu peristiwa dimana

\footnotetext{
Republik Indonesia, Putusan Mahkamah Konstitusi Nomor 072-073/PUU-II/2004.

Republik Indonesia, Putusan Mahkamah Konstitusi Nomor 81/ PUU-IX/2011.

Republik Indonesia, Putusan Mahkamah Konstitusi Nomor 92/PUU-XIV/2016.

59 MK berpendapat bahwa Pemilukada secara langsung yang berpegang teguh atas asas-asas pemilu dan diselenggarakan oleh lembaga KPU yang bersifat independen mustahil dapat tercapai apabila KPUD sebagai penyelenggara yang telah ditentukan harus bertanggung jawab terhadap kekuasaan legislatif maupun eksekutif. Republik Indonesia, Putusan Mahkamah Konstitusi Republik Indonesia Nomor 072-073/PUU-II/2004.
} 
peraturan perundang-undangan yang berlaku tidak mampu atau tidak cukup lengkap dalam mengakomodir peristiwa hukum atau tuntutan hukum di masyarakat. ${ }^{60}$ Adanya kekosongan hukum yang terjadi dapat berdampak kepada kekacauan dalam penerapan hukum di masyarakat oleh karena tidak terakomodirnya asas kepastian hukum dalam penerapan peraturan perundang-undangan. ${ }^{61}$

Pemberlakuan sebuah Perppu oleh Presiden juga didasarkan atas suatu kedaruratan sebagaimana telah dijelaskan sebelumnya. Kondisi kedaruratan yang mungkin dapat terjadi memberikan kewajiban kepada Pemerintah agar semua institusi negara dapat tetap berfungsi sebagaimana keadaan normal. ${ }^{62}$ Pemberlakuan Perppu di masa kedaruratan tidak dimungkinkan agar Pemerintah dapat secara sewenangwenang membubarkan institusi negara lainnya. ${ }^{63}$ Lebih lanjut Perppu Nomor 2 Tahun 2020 dalam substansinya justru mengatur perihal pengatribusian kewanangan kepada KPU agar lembaga ini dapat menjalankan tugasnya di masa pandemi covid-19.

Apabila kita menganalisis antara pemberlakuan Perppu Nomor 2 Tahun 2020 dengan makna independensi KPU dan KPUD sebagaimana tafsir MK dalam beberapa Putusan MK yang telah disebutkan, maka tidak terdapat korelasi yang menyatakan bahwa pemberlakuan Perppu Nomor 2 Tahun 2020 adalah bentuk intervensi Pemerintah terhadap independensi penyelenggaraan Pemilukada
Tahun 2020. Terganggunya independensi KPU dalam penyelenggaraan Pemilukada haruslah dinilai dari substansi pengaturan yang dibuat, bukan hanya oleh siapa peraturan tersebut dibuat. Ada pun Perppu Nomor 2 Tahun 2020 yang dalam substansinya mengatur mengenai pengatribusian kewenangan untuk menetapkan tanggal perubahan dari penundaan pemilukada serentak tahun 2020 adalah bentuk perbuatan pemerintah yang memperkuat KPU sebagai lembaga negara independen yang bertanggung jawab terhadap penyelenggaraan Pemilukada serentak tahun 2020. Selain itu, pemberlakuan Perppu Nomor 2 Tahun 2020 juga merupakan bentuk perbuatan pemerintah yang ditujukan guna mencegah terjadinya kekosongan hukum di masyarakat yang berpotensi mengakibatkan kekacauan penerapan hukum di masyarakat. Oleh sebab itu, dapat disimpulkan bahwasanya pembentukan Perppu Nomor 2 Tahun 2020 yang mengatur mengenai penundaan Pemilukada merupakan suatu hal yang bersifat konstitusional, dan dalam hal ini tidak terdapat bentuk intervensi Pemerintah yang mengakibatkan terganggunya independensi KPU sebagai lembaga penyelenggara Pemilu yang independen.

\section{Penutup}

Berdasarkan penelitian ini, dapat disimpulkan bahwa sebelum adanya Perppu Nomor 2 Tahun 2020, kedudukan KPU sebagai lembaga penyelenggara Pemilu belum memiliki

60 Bagir Manan dan Kuntana Magnar, Beberapa Masalah Hukum Tata Negara Indonesia, (Bandung: Alumni, 1993), hlm. 8.

61 Ibid.

62 Dian Kus Pratiwi, "Implikasi Yuridis Peraturan Pemerintah Pengganti Undang Undang Nomor 2 Tahun 2017 Tentang Perubahan Atas Undang Undang Nomor 17 Tahun 2013 Tentang Organisasi Kemasyarakatan di Indonesia”, Padjadjaran Jurnal Ilmu Hukum Volume 4 Nomor 2 (2017): 285.

63 Donald A. Rumokoy dan Carlo A. Gerungan, "Kajian Kewenangan Mahkamah Konstitusi Dalam Pengujian Peraturan Pemerintah Pengganti Undang Undang Berdasarkan Putusan Mahkamah Konstitusi No 138/PUU-VII/2009" Jurnal Lex Administratum Volume 8 Nomor 3 (2020): 23. 
kewenangan untuk menunda dan menetapkan jadwal pelaksanaan Pemilukada serentak akibat adanya bencana yang bersifat nasional. Adapun selama ini kewenangan untuk melakukan penundaan hanya dapat dilakukan pada daerah tertentu dengan izin pemberian kewenangan yang hierarkis pada tingkat provinsi ataupun kabupaten/kota. Kehadiran Perppu Nomor 2 Tahun 2020 tentang Perubahan Ketiga Atas Undang Undang Nomor 1 Tahun 2015 tentang Penetapan Peraturan Pemerintah Pengganti Undang-Undang Nomor 1 Tahun 2014 tentang Pemilihan Gubernur, Bupati, dan Walikota Menjadi Undang-Undang dapat dimaknai sebagai bentuk upaya Pemerintah dalam mencegah terjadinya kekosongan hukum dan menciptakan payung hukum dalam penyelenggaraan Pemilukada serentak 2020 di masa penyebaran Pandemi Covid-19.

Perlu dipahami bahwa keadaan darurat penyebaran Pandemi Covid-19 yang dideklarasikan oleh Presiden adalah bentuk pelaksana tugas pemerintah sesuai dengan UUD NRI 1945, sehingga pemberlakuan Perppu Nomor 2 Tahun 2020 sebagai bentuk respon terhadap penyebaran Pandemi Covid-19 merupakan bagian dari kebijakan hukum pemerintah tersebut. Lebih lanjut, di dalam kondisi keadaan darurat, pemerintah negara tetap bertanggung jawab atas penyelenggaraan tugas kenegaraan yang dijalankan oleh instutusi negara lainnya, termasuk KPU. Kehadiran dan pemberlakuan Perppu Nomor 2 Tahun 2020 tidak dapat dimaknai sebagai upaya untuk mengganggu independensi KPU dalam menjalankan tugasnya sebagai penyelenggara Pemilukada serentak tahun 2020. Adapun pemberlakuan Perppu Nomor 2 Tahun 2020 oleh Pemerintah adalah sebagai wujud penguatan kewenangan KPU sebagai lembaga penyelenggara Pemilukada serentak tahun 2020 melalui pengatribusian kewenangan untuk menetapkan tanggal perubahan Pemilukada serentak tahun 2020 sebagai akibat dari adanya penundaan yang disebabkan oleh Pandemi Covid-19. Oleh sebab itu, dapat disimpulkan bahwa penerbitan Perppu oleh Presiden ini merupakan suatu hal yang bersifat konstitusional dan bukan merupakan bentuk intervensi Pemerintah yang mengakibatkan terganggunya independensi KPU sebagai lembaga penyelenggara Pemilu. 


\section{Daftar Pustaka}

\section{A. Buku}

Abdullah, Rozali, Pelaksanaan Otonomi Luas dengan Pemilihan Kepala Daerah Secara Langsung (Jakarta: Rajawali Pers, 2005).

Asshiddiqie, Jimly dan M. Ali Safa'at, Teori Hans Kelsen Tentang Hukum (Jakarta: Mahkamah Konstitusi Republik Indonesia, 2006).

Asshiddiqie, Jimly, Hukum Tata Negara Darurat (Jakarta: Raja Grafindo Persada, 2007).

Azed, Abdul Bari dan Amir Makmur, Pemilu dan Partai Politik di Indonesia (Jakarta: Pusat Studi Hukum Tata Negara Fakultas Hukum Universitas Indonesia, 2013).

Budiardjo, Miriam, Ilmu Politik (Jakarta: Gramedia Pustaka Utama, 1982).

Huda, Ni'matul, Politik Ketatanegaraan Indonesia (Yogyakarta: FH UII Press, 2003).

Manan, Bagir dan Kuntana Magnar, Beberapa Masalah Hukum Tata Negara Indonesia (Bandung: Alumni, 1993).

MD, Mahfud, Politik Hukum di Indonesia (Jakarta: RajaGrafindo Persada, 2014).

Triwulan, Titik Triwulan dan H. Ismu Gunadi Widodo, Hukum Tata Usaha Negara dan Hukum Acara Peradilan Tata Usaha Negara Indonesia (Jakarta: Kencana Prenada Media Group, 2003).

\section{B. Artikel IImiah}

Alfyana, Fajar, "KPU dan Konsolidasi Demokrasi: Studi Terhadap Independensi KPU Kota Makassar", Jurnal Vox Populi 2, no. 2 (2019).

Ansori, "Legalitas Hukum Komisi Pemilihan Umum Daerah dalam Menyelenggarakan Pilkada", Jurnal Konstitusi 14, no. 3 (2017).

Ansori, Jazim Hamidi, dan Muhammad Ali Safa'at, "Kedudukan Hukum Komisi Pemlihan Umum Daerah dalam Menyelengarakan Pemilihan Kepala Daerah Pasca Putusan MK Nomor 97/PUU-XI/2013", Jurnal Mahasiswa Fakultas Hukum (2016).

Asshiddiqie, Jimly, "Diktator Konstitusional dan Hukum Pengecualian" (paper disampaikan pada Webinar Perkembangan Hukum Tata Negara Darurat di Indonesia, Jakarta, 30 April 2020).

Asshiddiqie, Jimly, "Dua tipe Perppu" (paper disampaikan pada Webinar Perkembangan Hukum Tata Negara Darurat di Indonesia, Jakarta, 30 April 2020).

Azed, Abdul Bari, "Sistem Pemilihan Umum di Indonesia", Jurnal Hukum dan Pembangunan (1987).

Damela, Lindra, "Tinjauan Sistem Hukum dalam Penerapan Peraturan Daerah Syari'ah di Tasikmalaya". Jurnal IImu Syari'ah dan Hukum 50, no. 1 (2015).

Hsb, Ali Marwan, "Pemilihan Kepala Daerah yang Demokratis Berdasarkan Putusan Mahkamah Konstitusi Nomor 97/PUU-IX/2013", Jurnal Legislasi Indonesia 13, no. 3 (2016).

Hudi, Mohammad, "Kedudukan Dan Tanggung Jawab Presiden Dalam Sistem Presidensial Di Indonesia", Mimbar Yustisia 2, no. 2 (2018).

Pratiwi, Dian Kus, "Implikasi Yuridis Peraturan Pemerintah Pengganti Undang Undang Nomor 2 Tahun 2017 Tentang Perubahan Atas Undang Undang Nomor 17 Tahun 2013 Tentang Organisasi Kemasyarakatan di Indonesia", Padjadjaran Jurnal IImu Hukum 4, no. 2 (2017).

Rumokoy, Donald A. dan Carlo A. Gerungan, "Kajian Kewenangan Mahkamah Konstitusi 
Dalam Pengujian Peraturan Pemerintah Pengganti Undang Undang Berdasarkan Putusan Mahkamah Konstitusi No 138/PUU-VII/2009" Lex Administratum VIII, no. 3 (2020).

Saraswati, Retno, "Legalitas Hukum Komisi Pemilihan Umum Daerah dalam

Menyelenggarakan Pilkada", Jurnal Dinamika Hukum 14, no. 3 (2014).

Yani, Ahmad, "Sistem Pemerintahan Indonesia: Pendekatan Teori Dan Praktek Konstitusi

Undang Undang Dasar 1945", Jurnal Legislasi 15, no. 2 (2018).

Zamroni, Mohammad, "Kekuasaan Presiden Dalam Mengeluarkan Perppu", E-Jurnal

Peraturan (2015), https://e-jurnal.peraturan.go.id/index.php/jli/article/view/410

(diakses 8 Oktober 2020).

Zulbaidah dan Zulkarnaen, "Pertanggungjawaban Presiden di Indonesia Berdasarkan UUD 1945", Jurnal Varia Hukum 1, no. 1 (2019).

\section{Internet}

Pontianak Post, "Belajar dari Suksesnya Korea Selatan Gelar Pemilu Saat Pandemi", https:// pontianakpost.co.id/belajar-dari-suksesnya-korea-selatan-gelar-pemilu-saat-pandemi/ (diakses 12 Juni 2020).

\section{Peraturan Perundang-Undangan dan Putusan}

Undang-Undang Dasar Negara Republik Indonesia Tahun 1094

Undang-Undang Nomor 32 Tahun 2004 Tentang Pemerintahan Daerah

Undang-Undang Nomor 1 Tahun 2015 Tentang Undang-Undang Penetapan Peraturan Pemerintah Pengganti Undang-Undang Nomor 1 Tahun 2014 tentang Pemilihan Gubernur, Bupati, dan Walikota Menjadi Undang-Undang

Undang-Undang Nomor 8 Tahun 2015 Tentang Perubahan Pertama atas Undang-Undang Nomor 1 Tahun 2015 Tentang Undang-Undang Penetapan Peraturan Pemerintah Pengganti Undang-Undang Nomor 1 Tahun 2014 tentang Pemilihan Gubernur, Bupati, dan Walikota Menjadi Undang-Undang

Undang-Undang Nomor 10 Tahun 2016 Tentang Perubahan Kedua atas Undang-Undang Nomor 1 Tahun 2015 Tentang Undang-Undang Penetapan Peraturan Pemerintah Pengganti Undang-Undang Nomor 1 Tahun 2014 tentang Pemilihan Gubernur, Bupati, dan Walikota Menjadi Undang-Undang

Undang-Undang Nomor 7 Tahun 2017 Tentang Pemilihan Umum

Peraturan Pemerintah Pengganti Undang-Undang Tentang Perubahan Ketiga Atas Undang Undang Nomor 1 Tahun 2015 Tentang Penetapan Peraturan Pemerintah Pengganti Undang-Undang Nomor 1 Tahun 2014 tentang Pemilihan Gubernur, Bupati, dan Walikota Menjadi Undang-Undang

Peraturan Komisi Pemilihan Umum Nomor 15 Tahun 2019 Tentang Tahapan, Program, dan Jadwal Penyelenggaraan Gubernur dan Wakil Gubernur, Bupati dan Wakil Bupati, dan/ atau Walikota dan Wakil Walikota Tahun 2020

Keputusan KPU Nomor 179/PI.02-KPT/01/KPU/lii/2020 Tentang Penundaan Tahapan Pemilihan Gubernur dan Wakil Gubernur, Bupati dan Wakil Bupati, dan/atau Wali Kota Dan Wakil Wali Kota Tahun 2020 dalam Upaya Pencegahan Penyebaran Covid-19

Putusan Mahkamah Konstitusi Nomor 138/PUU-VII/2009. 


\section{BIODATA PENULIS}

Farida Azzahra, S.H. saat ini merupakan mahasiswa Pascasarjana Fakultas Hukum Universitas Indonesia dengan peminatan Hukum Kenegaraan. Sebelumnya, Farida menamatkan Studi S1 dari Universitas Krisnadwipayana. Farida pernah bekerja sebagai penulis di media JejakParlemen.id (2018) dan juga pernah mengikuti program magang sebagai Staf Analis Kebijakan Bidang Pemerintahan di DPRD Provinsi DKI Jakarta (2019). Saat ini, Farida aktif di kegiatan kemahasiswaan kampus dan menjabat sebagai Ketua Departemen Jurnal dan Pengabdian Masyarakat Ikatan Mahasiswa Magister Hukum Universitas Indonesia. Selain itu, Farida juga aktif terlibat sebagai peneliti di Organisasi non Pemerintah, Indonesia Berbicara.

Aloysius Eka Kurnia, S.H. saat ini merupakan mahasiswa Pascasarjana Fakultas Hukum Universitas Indonesia dengan peminatan Hukum Kenegaraan. Eka menamatkan Studi S1 dari Fakultas Hukum Universitas Katolik Parahyangan pada tahun 2018. Eka pernah bekerja sebagai asisten advokat di Lokataru Law and Human Rights Office (2018), asisten advokat di Kantor Hukum Maruarar Siahaan and Partners (2019), dan juga melaksanakan magang sebagai Staf Analis Kebijakan Bidang Pemerintahan di DPRD Provinsi DKI Jakarta (2019). Saat ini Eka bekerja sebagai asisten dosen di Fakultas Hukum Universitas Katolik Parahyangan. 